\title{
From a Digital Bottle: A Message to Ourselves in 2039
}

Alejandro R Jadad ${ }^{1}$, MD, DPhil; Tamen M Jadad Garcia ${ }^{2}$, BSc

${ }^{1}$ Dalla Lana School of Public Health, University of Toronto, Toronto, ON, Canada

${ }^{2}$ Beati Inc, Toronto, ON, Canada

\section{Corresponding Author:}

Alejandro R Jadad, MD, DPhil

Dalla Lana School of Public Health

University of Toronto

155 College St, 6th Floor

Suite 2404

Toronto, ON, M5T 3M7

Canada

Phone: 14163585631

Email: a.jadad@utoronto.ca

\begin{abstract}
We are fully aware that we could have wasted our time writing this message, as nobody might read it. Even those who read it might ignore it, and those who read and care about it might be unable to do anything. It may simply be too late. Nevertheless, this message describes the hopes we had back in 1999, imagining how the incredible digital tools whose birth we were witnessing, could change the world for the better. In 2019, when we wrote these words, we were saddened to realize that most of what we had imagined and proposed in the past 20 years could have been written the day before, without losing an iota of relevance. Whoever or whatever you might be, dear reader — a human, a sentient machine, or a hybrid — we would like you to understand that, rather than an attempt to predict the future, which probably continues to be an impossible endeavor, this message was meant to act as an invitation, regardless of when or where it is found, to engage in a conversation that has already transcended time and space, even if the issues it contains have become irrelevant.
\end{abstract}

(J Med Internet Res 2019;21(11):e16274) doi: 10.2196/16274

\section{KEYWORDS}

wisdom; pandemic; concepts; future; extinction; self-sabotage; precariat; stupidity; noosphere; capitalism

To whom might read this, human or sentient machine:

We are fully aware that we could have wasted our time writing this message, as nobody might read it. Even those who read it might ignore it, and those who read and care about it might be unable to do anything. It may simply be too late.

We would like to share with you the hopes we had back in 1999, imagining how the incredible digital tools whose birth we were witnessing, could change the world for the better. As a Babyboomer father, who, as a physician, had started communicating with patients via email in 1990 and a Millennial daughter who saw ways to improve healthcare since her infancy [1], we have spent the last two decades dreaming about and proposing new possibilities that would enable everyone to enjoy a healthy life.

It saddens us to realize that most of what we had imagined and proposed in the past two decades could have been written yesterday, without losing an iota of relevance today.
Twenty years ago, we imagined new forms of partnerships between healthcare professionals and the public [2-4], enlightened by trustworthy information, available anywhere, in the right format, in the right amount, with the right balance [5-8]. We called for a major shift "from our ethic of competition and narrow self interest, focused on gadgets-to one of generosity and collaboration, centred on people." [9]

Instead, we are now facing an avalanche of "fake" or misleading knowledge that is capable of reaching the masses more effectively than verified facts, particularly through social media [10]. This has opened the door to new spaces for hate speech and manipulation of public opinion, undermining trust and hindering efforts to control diseases that should have been eradicated already, or that could otherwise be managed easily [10-12].

In the past two decades, we dreamed about ways in which we could use every new technological development to create tailored services, available to all people, that could transcend 
our traditional geographic, cultural, religious, institutional, and political boundaries [13-15]. We believed that it was possible to join forces across the world to imagine and reinvent how we care for each other, through the enthusiastic and proficient use of information and communication technologies [16,17].

Instead, in 2019, we face a landscape littered by variations in the same disconnected examples that have been used for two decades to illustrate how digital tools could contribute to the prevention, diagnosis, or treatment of diseases. Sadly, the promises of information and communication technologies to transform healthcare services remain unfulfilled as a result of poorly designed interfaces, persistently increasing workload for providers, unresolved privacy concerns, lack of sensible models for the reimbursement of new services, chronically outdated communication skills, and obsolete rules of etiquette to guide interactions at all levels $[18,19]$.

We also imagined new possibilities to unlearn, to "un-see" and "un-believe" in the barriers that prevent us from having a full life, from before our first breath to the last one [20]. We dreamed that we could look at death as the main source of insights that could inspire us to live fully, without fear, regrets or distress, through all stages of our lives [21-23].

Instead of broadening our understanding of the mental and social aspects of our lives, we kept steering our technological innovations to go deeper and deeper into the body. Since the turn of the 20th century, informatics has enabled an explosion in the biological understanding of what ails us, bringing back the dreams of yore about our capacity to personalize medical responses to physical challenges. Such insights, nevertheless, have also emboldened the medical industrial complex to boost its efforts to create sophisticated weapons to feed the war against diseases. The infatuation around "fixing" physical problems is now manifesting through an apparently inexhaustible menu of ever-reductionist "omics" [24,25], which are taking the chemical-mechanical view of humanity to new depths [26] while feeding a frantic new era of hypermedicalization of life. Instead of being a source of humility and insights, death has now become something for which there might be a "cure" [27].

During the past two decades, we used online platforms to nurture a global conversation about the meaning of health [28,29]. This led to a new conceptualization that views it as the ability, which anyone could develop, to adapt and manage the inevitable challenges we face through life as individuals or communities [30]. We invited the world to unleash a pandemic of health through the enlightened and generous use of digital technologies [31,32]. We viewed the internet as a treasure trove of opportunities to celebrate and boost the "high-touch" with the "high-tech" [16].

Rather than using them to usher in truly planet-wide, open, equitable, affordable services that are culturally sensitive and tailored to our unique needs and those of other living beings, sophisticated digital platforms are accelerating the privatization and segmentation of a "sickcare" system in practically every region of the world while transforming it into a branch of the financial system [33]. The same phenomenon of "financialization," driven by global digital platforms and algorithms, has engulfed all other aspects of human life, compounding the threats to health at all levels, from the individual to the planetary level. Digital technologies are at the core of the engines that have made 2019 a year full of nefarious records in terms of global warming, major weather events, deforestation, and extinction of animal and plant species [34-37]. As a result, environmental factors have become the main cause of one quarter of all deaths in the world [38].

We hoped, above all, that digital technologies would enable us to prevail, transforming us into "humanodes" in a global superorganism, feeding a Noosphere-a planetary thinking network of reasoning minds - in which we all could divert our seemingly unavoidable course toward a world without humans to one in which we would thrive [39].

We were naive...

The opportunities we have had over the last 20 years appear to have been "insurmountable."

Instead of realizing the dream of a humanity that could be connected deeply and meaningfully into an enlightened whole, technology over the past 20 years has been used, relentlessly, to dismantle communities and societies around the world, segmenting them all the way to the individual level [40]. This extreme level of "precision capitalism," which is fueled by social media, is leading to unprecedented levels of isolation [41], making loneliness a growing source of preventable deaths [42] and low levels of well-being [43].

Our growing disconnection from each other is also facilitating the emergence of new economic models ruled by a progressively smaller group of unaccountable masters who have unleashed a growing network of all-powerful algorithms. Such models consider the vast majority of humans either as consumers of the goods or services they peddle or as biological automatons that are relevant only because they are capable of performing tasks that machines are still unable to complete or because they are less expensive [44].

The relegation of humans to the margins of the economy is breeding fresh threats to health, which multiply and reinforce each other as technology takes over every aspect of human life. A case in point is the impact that automation and artificial intelligence are having on existing occupations and on the ways in which humans make a living. As machines and artificial intelligence gain dominance, a new class of unfortunate humans is emerging, under the guise of freedom [45]. Known collectively as "the precariat," these are people who are self-employed or freelancers, doing mostly "gig jobs" without long-term or permanent contracts [46]. Often, they are overqualified individuals who work under short-term or zero-hour contracts, sometimes for a few minutes at a time, without benefits provided by employers [47]. Even physicians are now at risk of joining this class [48].

With the pervasive use of digital technology driving people into precariousness, marketeers, engineers, and scientists at the service of the new unchecked overlords have also devised new tricks to extract the remaining disposable income available to the helpless masses. In 2019, people's attention has become the main target [49]. As a result, digital devices_or, more precisely, the experiences they purvey-have been manipulated to become 
increasingly addictive, thanks to constant monitoring and experimentation on consumers through the platforms they use and the data they produce [50]. This has generated new problems, such as those associated with gaming, gambling, or over-consumption of social media, and in the invigoration of old ones, manifested through shopaholism, workaholism, eating disorders, online pornography, or the rapid proliferation of electronic cigarettes [51].

In 2019 , the new threats created by the massive digitalization of the planet are finding all those charged with safeguarding or improving human health wanting. Front line healthcare providers, in particular, are ill equipped to face the vastly complex array of new challenges. In the past 20 years, instead of becoming examples of how to lead healthy lives, physicians and nurses are facing high levels of depression, stress, anxiety, and burnout [52-55]. The prevalence of addiction is likely similar or higher among physicians when compared with the general public [56]. They also commit suicide more often, with women at an even greater risk [57]. In fact, suicide is the only cause of death that has a higher prevalence among physicians than the general population. Male physicians are $40 \%$ more likely than members of the general public to kill themselves, while the risk is more than double for female physicians [58]. The situation among nurses is likely similar $[59,60]$.

As we kill ourselves in ever more creative ways, the ability of machines to control those who will remain alive is increasing. As the so-called "The Internet of Things" materializes, a practically unimaginable number of interconnected devices, compounded by our cavalier ways to share our information with corporations, governments and financial institutions is curtailing our freedom. Insidiously, we are becoming prisoners in a digital panopticon run by a surveillance capitalist apparatus [61]. Given that it is estimated that the number of connected computing devices will exceed one trillion in the next 20 years [62], we are facing a world in which instead of humans controlling the Internet of Things, we could become one of the many things controlled by the internet [63].

We can no longer afford to be oblivious to what is obvious.

The space for humanity to flourish in the middle of a spectrum spanning from apocalyptic and transhumanist extremes has narrowed significantly in the past 20 years [64]. We might be facing the worst possible scenario: a self-inflicted apocalyptic posthuman era, brought about by our seemingly unstoppable propensity to self-sabotage.

Instead of using our digital offspring to nurture the Noosphere, we have created the "Atesphere"-after Ate, the goddess of delusion, blind folly, and ruin [65]—an interconnected planetary layer of human stupidity, fed by our self-harming tendencies. Within it, we are hastening our complete or near-complete extinction.

To counterbalance the risk that such a pessimistic stance could lead to a self-fulfilling prophecy, we would like to put forward a counter argument [66]: It is also possible for humans and machines to create a "Sophosphere," a planetary network of interconnected people, machines, and all other living things striving to negate self-sabotage through wisdom.

We believe that wisdom could be the best antidote to self-sabotage because, based on a conceptualization proposed in 1999 [67], we view it as "the ability to know what it is to live well, and do everything possible to achieve this, given the circumstances, while enabling others to do the same, as a means to overcome the destructive mental processes and behaviours that inhibit our own ability to experience a full life, in our own way, together." This approach, which we feel adds balance to the Atesphere, makes it possible for machines to be wise too and for machines and humans to collaborate and create the conditions needed to live well in harmony with other living things.

In a consistently mirror-like fashion, the Sophosphere might occur, as a Big Bang, in response to the devastating effects of the Atesphere at its peak. Just as it happens with individuals who undergo a near-death experience, it has been suggested that our species could go through a similar process, snapping back from the brink of death, en masse, to embrace radically different priorities and values and be ready to live fully [68].

Another option, also counterintuitive, involves doing nothing, on the basis of the belief that our frantic efforts to make change happen might be part of the problem, rather than part of the solution. Instead, this approach calls for restraint and patience, as it regards massive social change as a nonlinear phenomenon that could happen suddenly, in response to the accumulation of little adjustments made by large enough numbers of individuals or small groups to their own lives [69].

In addition, the Sophosphere could emerge more deliberately, through the collective efforts of innovators from different sectors, joining forces in and from different regions of the world to incubate new ways to coexist harmoniously, which could then spread, through social contagion, until they become pandemic [32].

As noted a few years ago, the most sensible option might be hardest to accept, as it requires recognizing that humanity is terminally ill as the result of self-inflicted wounds, and that the wisest course of action is to engage in palliative care measures at a species level [39].

Having reached this point, dear reader, whoever or whatever you might be, we would like you to understand that, rather than an attempt to predict the future, which is impossible, this message that was released into the cyberwaves in 2019 should be viewed as an invitation, regardless of when or where it is found, to engage in a conversation that has already transcended time and space, even if the issues it contains have become irrelevant.

We will only know what will happen when it happens.

\section{Conflicts of Interest}

None declared. 


\section{Multimedia Appendix 1}

[PNG File, 1602 KB-Multimedia Appendix 1]

\section{References}

1. Jadad AR. A view from the Internet age: let's build a health system that meets the needs of the next generation. CMAJ 2004 Dec 07;171(12):1457-1458 [FREE Full text] [doi: 10.1503/cmaj.1041276] [Medline: 15583185]

2. Jadad AR. Promoting partnerships: challenges for the internet age. BMJ 1999 Sep 18;319(7212):761-764. [doi: 10.1136/bmj.319.7212.761]

3. Jadad AR. I am a good patient, believe it or not. BMJ 2003 Jun 12;326(7402):1293-1295. [doi: 10.1136/bmj.326.7402.1293]

4. O'Grady L, Jadad A. Shifting from Shared to Collaborative Decision Making: A Change in Thinking and Doing. J Particip Med 2012;34(19):1608-1616.

5. Jadad AR, Gagliardi A. Rating Health Information on the Internet. JAMA 1998 Feb 25;279(8):611. [doi: 10.1001/jama.279.8.611]

6. Gagliardi A, Jadad A. Examination of instruments used to rate quality of health information on the internet: chronicle of a voyage with an unclear destination. BMJ 2002 Mar 09;324(7337):569-573 [FREE Full text] [doi: 10.1136/bmj.324.7337.569] [Medline: 11884320 ]

7. Jadad A. The Internet and evidence-based decision-making: a needed synergy for efficient knowledge management in health care. J Med Internet Res 2000 Sep 13;2:e2. [doi: 10.2196/jmir.2]

8. Eysenbach G, Jadad AR. Evidence-based patient choice and consumer health informatics in the Internet age. J Med Internet Res 2001 Jun 7;3(2):E19 [FREE Full text] [doi: 10.2196/jmir.3.2.e19] [Medline: 11720961]

9. Jadad AR, Delamothe T. What next for electronic communication and health care? BMJ 2004 May 13;328(7449):1143-1144. [doi: $10.1136 / \mathrm{bmj} .328 .7449 .1143$ ]

10. Finn P. The Impact of Social Media on Communication Sciences and Disorders: A Need for Examination and Research. Perspect ASHA SIGs 2019 Apr 15;4(2):224-227 [FREE Full text] [doi: 10.1044/2019 pers-st-2019-0001]

11. Shoup JA, Narwaney KJ, Wagner NM, Kraus CR, Gleason KS, Albright K, et al. Social Media Vaccine Websites: A Comparative Analysis of Public and Moderated Websites. Health Educ Behav 2019 Jun 29;46(3):454-462. [doi: 10.1177/1090198118818253] [Medline: 30596265$]$

12. Armstrong PW, Naylor CD. Counteracting Health Misinformation. JAMA 2019 May 21;321(19):1863. [doi: 10.1001/jama.2019.5168]

13. Jadad A, Goel V, Rizo C, Hohenadel J, Cortinois A. The global e-health innovation network - Building a vehicle for the transformation of the health system in the information age. Business Briefing: Next Generation Healthcare 2000;48:54.

14. Cortinois A, Downey S, Closson T, Jadad A. Hospitals in a globalized world: a view from Canada. Healthc Pap 2003;4(2):14-32. [Medline: 14660881]

15. Shachak A. Electronic Health Records in the Age of Social Networks and Global Telecommunications. JAMA 2010 Feb 03;303(5):452. [doi: 10.1001/jama.2010.63]

16. Balliol College, University of Oxford. 2007. An innovator in global healthcare and human well-being URL: https://www. balliol.ox.ac.uk/alumni-and-friends/floreat-domus/2007/an-innovator-in-global-healthcare-and-human-well-being [accessed 2019-10-15]

17. Jadad AR, Serra M, Palacio D, Espinal S, Rodriguez D, editors. Trusted networks: The Key to Achieve World-class Health Outcomes on a Shoestring. Toronto, ON: Beati Inc; 2018.

18. The Lancet. 2019 Apr 04. Barriers and Facilitators for Implementation of Electronic Consultations (eConsult) to Enhance Access to Specialist Care: A Scoping Review URL: https://papers.ssrn.com/abstract=3365087 [accessed 2019-10-15]

19. Schraeder T. Physician Communication: Connecting with Patients, Peers, and the Public. Oxford, UK: Oxford University Press; 2019.

20. Jadad AR. Unlearning: Incomplete Musings On The Game Of Life And The Illusions That Keep Us Playing. Toronto, ON: Foresight Press; 2008.

21. Enkin M, Jadad AR, Smith R. Death can be our friend. BMJ 2011 Dec 21;343(dec21 2):d8008-d8008. [doi: 10.1136/bmj.d8008]

22. Herrera-Molina E, Librada S, Lucas M, Jadad-Garcia T, Rodriguez S, Jadad A. The New Health Foundation: Transforming palliative care through the integration of clinical and social services, and community engagement. Eur J Palliat Care 2017;24:123-125.

23. Herrera E, Jadad-Garcia T, Librada S, Alvarez A, Rodriguez Z, Lucas M, et al, editors. Beginning from the End: Enabling the transformation of how we care for each other by bringing together the power of health and social services, and the community, during the last stages of life. Seville, Spain: New Health Foundation; 2017.

24. Lu Y, Chang Y, Hoffman E, Yu G, Herrington D, Clarke R, et al. Integrated Identification of Disease Specific Pathways Using Multi-omics data. bioRxiv 2019 Jun 11 [FREE Full text] [doi: $\underline{\text { 10.1101/666065] }}$

25. Deshmukh A. Gene and disease: an ?omics? as the pillars of systems. World J Pharm Res 2019;8(6):216. 
26. Glouberman S. The Mechanical Patient: Finding a More Human Model of Health. Milton Park, UK: Productivity Press; 2018.

27. Spivak J. HeinOnline. 2019. Redefining Life: The Constitutional Implications of Patenting Immortality URL: https:/ /heinonline.org/HOL/LandingPage?handle=hein.journals/caelj37\&div=35\&id=\&page= [accessed 2019-10-28]

28. Jadad AR, O'Grady L. The BMJ opinion. 2008 Dec 08. A global conversation on defining health URL: https://blogs.bmj.com/ bmj/2008/12/10/alex-jadad-on-defining-health/ [accessed 2019-10-15]

29. Jadad AR, O'Grady L. How should health be defined? BMJ 2008 Dec 10;337(dec10 1):a2900-a2900. [doi: 10.1136/bmj.a2900]

30. Huber M, Knottnerus JA, Green L, van der Horst H, Jadad AR, Kromhout D, et al. How should we define health? BMJ 2011 Jul 26;343(jul26 2):d4163-d4163. [doi: 10.1136/bmj.d4163] [Medline: 21791490]

31. Jadad AR. Creating a pandemic of health: What is the role of digital technologies? J Public Health Policy 2016 Nov 29;37(Suppl 2):260-268. [doi: 10.1057/s41271-016-0016-1] [Medline: 27899800]

32. Jadad AR, Arango A, Sepúlveda J, Espinal S, Rodriguez D, Wind K, editors. Unleashing a pandemic of health from the workplace: Believing is seeing. Toronto, ON: Beati Inc; 2017.

33. Hunter BM, Murray SF. Deconstructing the Financialization of Healthcare. Development and Change 2019 Jun 06;50(5):1263-1287. [doi: 10.1111/dech.12517]

34. Graham F. Nature. 2019 Aug 21. Daily briefing: July was the hottest month ever recorded on Earth URL: http://www. nature.com/articles/d41586-019-02536-1 [accessed 2019-10-15]

35. Gibbens S. National Geographic. 2019. The Amazon is burning at record rates-and deforestation is to blame URL: https:/ /www.nationalgeographic.com/environment/2019/08/wildfires-in-amazon-caused-by-deforestation/ [accessed 2019-10-15]

36. Lewis M. Electrek. 2019 Sep 14. Climate Crisis Weekly's extreme weather breaks records URL: https://electrek.co/2019/ 09/14/climate-crisis-weekly-2019-extreme-weather-breaks-records-un-climate-change-threatens-human-rights/ [accessed 2019-10-15]

37. IPBES. 2019. Nature's dangerous decline 'unprecedented,' species extinction rates 'accelerating' URL: $\underline{\text { https://www.ipbes.net/ }}$ news/Media-Release-Global-Assessment [accessed 2019-10-15]

38. The Global Environment Outlook. 2019. UNEnvironment URL: https://www.unenvironment.org/interactive/ global-environment-outlook/ [accessed 2019-10-15]

39. Jadad AR, Enkin M. Does humanity need palliative care? European Journal of Palliative Care 2017 May:102-103.

40. Rushkoff D. Team Human. In: Team Human. New York, NY: WW Norton \& Company; 2019:256.

41. Twenge JM, Spitzberg BH, Campbell WK. Less in-person social interaction with peers among U.S. adolescents in the 21st century and links to loneliness. Journal of Social and Personal Relationships 2019 Mar 19;36(6):1892-1913. [doi: $10.1177 / 0265407519836170]$

42. Williams SE, Braun B. Loneliness and Social Isolation-A Private Problem, A Public Issue. Journal of Family \& Consumer Sciences 2019 Feb 01;111(1):7-14. [doi: 10.14307/jfcs111.1.7]

43. Twenge JM. More Time on Technology, Less Happiness? Associations Between Digital-Media Use and Psychological Well-Being. Curr Dir Psychol Sci 2019 May 22;28(4):372-379. [doi: 10.1177/0963721419838244]

44. Berardi F. Futurability: The Age of Impotence and the Horizon of Possibility. Brooklyn, NY: Verso; 2019.

45. Conen W, Schippers J. Self-Employment as Precarious Work A European Perspective. In: Self-employment: between freedom and insecurity. Cheltenham, UK: Edward Elgar Publishing; 2019.

46. Raskin J. CounterPunch. Mar 19. Guy Standing on Anxiety, Anger and Alienation: an Interview About The Precariat URL: https://www.counterpunch.org/2019/03/19/guy-standing-on-anxiety-anger-and-alienation-an-interview-about-the-precariat/ [accessed 2019-10-15]

47. Godlewska-Bujok B, Patulski A. Precarious Work. In: Precariat: next stage of development or economic predominance in a new scene?. Cheltenham, UK: Edward Elgar Publishing; 2019.

48. Shah NR. Health Care in 2030: Will Artificial Intelligence Replace Physicians? Ann Intern Med 2019 Feb 26;170(6):407 [FREE Full text] [doi: 10.7326/m19-0344]

49. Franck G. The economy of attention. Journal of Sociology 2018 Nov 27;55(1):8-19. [doi: 10.1177/1440783318811778]

50. Berthon P, Pitt L, Campbell C. Addictive De-Vices: A Public Policy Analysis of Sources and Solutions to Digital Addiction. Journal of Public Policy \& Marketing 2019 Jul 28;38(4):451-468. [doi: 10.1177/0743915619859852]

51. Choi J, King DL, Jung Y. Editorial: Neurobiological Perspectives in Behavioral Addiction. Front Psychiatry 2019 Jan 22;10:3-3 [FREE Full text] [doi: 10.3389/fpsyt.2019.00003] [Medline: 30723426]

52. Williams E, Rathert C, Buttigieg S. The Personal and Professional Consequences of Physician Burnout: A Systematic Review of the Literature. Med Care Res Rev 2019 Jun 19:1077558719856787. [doi: 10.1177/1077558719856787] [Medline: $\underline{31216940]}$

53. Hoff T, Carabetta S, Collinson GE. Satisfaction, Burnout, and Turnover Among Nurse Practitioners and Physician Assistants: A Review of the Empirical Literature. Med Care Res Rev 2019 Feb 13;76(1):3-31. [doi: 10.1177/1077558717730157] [Medline: 28901205]

54. Yu F, Raphael D, Mackay L, Smith M, King A. Personal and work-related factors associated with nurse resilience: A systematic review. Int J Nurs Stud 2019 May;93:129-140. [doi: 10.1016/j.ijnurstu.2019.02.014] [Medline: 30925279] 
55. Petrie K, Crawford J, Baker STE, Dean K, Robinson J, Veness BG, et al. Interventions to reduce symptoms of common mental disorders and suicidal ideation in physicians: a systematic review and meta-analysis. The Lancet Psychiatry 2019 Mar;6(3):225-234. [doi: 10.1016/s2215-0366(18)30509-1]

56. Angie CC, Leung T. Substance Use Disorders. In: Weiss Roberts L, Trockel M, editors. The Art and Science of Physician Wellbeing: A Handbook for Physicians and Trainees. Berlin, Germany: Springer International Publishing; 2019.

57. Dutheil F, Aubert C, Pereira B, Dambrun M, Moustafa F, Mermillod M. Lancet. 2019 Jun 07. Suicide Among Physicians and Health-Care Workers: A Systematic Review and Meta-Analysis URL: https://papers.ssrn.com/abstract=3397193 [accessed 2019-10-15]

58. Albuquerque J, Tulk S. Physician suicide. CMAJ 2019 May 06;191(18):E505-E505. [doi: 10.1503/cmaj.181687] [Medline: 31061076]

59. Davidson J, Proudfoot J, Lee K, Zisook S. Arch Psychiatr Nurs. 2019 Jun 8. Nurse suicide in the United States: Analysis of the Center for Disease Control 2014 National Violent Death Reporting System dataset URL: http://www.sciencedirect.com/ science/article/pii/S0883941719300287 [accessed 2019-10-15]

60. Mumba M, Kraemer K. Substance Use Disorders among Nurses in Medical-Surgical, Long-Term Care, and Outpatient Services. Medsurg Nurs 2019;28(2):118.

61. Zuboff S. The age of surveillance capitalism: The fight for a human future at the new frontier of power. New York, NY: PublicAffairs; 2019.

62. Anonymous. The Economist. 2019. How the world will change as computers spread into everyday objects URL: https:/ /www.economist.com/leaders/2019/09/12/how-the-world-will-change-as-computers-spread-into-everyday-objects [accessed 2019-10-15]

63. Hendricks VF, Vestergaard M, editors. Epilogue: Digital Roads to Totalitarianism. In: Reality Lost: Markets of Attention, Misinformation and Manipulation. Berlin, Germany: Springer International Publishing; 2019:119.

64. Jadad AR, Enkin MW. Computers: transcending our limits? BMJ 2007 Jan 06;334(suppl_1):s8-s8. [doi: 10.1136/bmj.39038.663970.94]

65. ATE. URL: https://www.theoi.com/Daimon/Ate.html [accessed 2019-10-15]

66. Benoit L, Russo T, Barry C, Falissard B, Henckes N. "You have to believe in something": Risk of psychosis and psychiatrists' beliefs in the self-fulfilling prophecy. Soc Sci Med 2019 Jun;230:20-29. [doi: 10.1016/j.socscimed.2019.03.035] [Medline: 30947102]

67. Ryan S. What is wisdom? Philos Stud 1999;93(2):39.

68. Dossey L. Possibilities for the Survival of the Human Race: A Global Near-Death Experience. Explore (NY) 2018 Jul;14(4):241-247. [doi: 10.1016/j.explore.2018.04.001] [Medline: 29859823]

69. Poland B. Coming Back to Our True Nature: What Is The Inner Work that Supports Transition? In: Zywert K, Quilley S, editors. Health in the Anthropocene. Toronto, ON: University of Toronto Press; 2019.

Edited by G Eysenbach; submitted 15.09.19; peer-reviewed by M Focsa; comments to author 11.10.19; revised version received
16.10.19; accepted 17.10.19; published 01.11.19
Please cite as:
Jadad AR, Jadad Garcia TM
From a Digital Bottle: A Message to Ourselves in 2039
J Med Internet Res $2019 ; 21(11):$ :16274
URL: $\underline{\text { https://www.jmir.org/2019/11/e16274 }}$
doi: $\underline{10.2196 / 16274}$
PMID: $\underline{31682578}$

(CAlejandro R Jadad, Tamen M Jadad Garcia. Originally published in the Journal of Medical Internet Research (http://www.jmir.org), 01.11.2019. This is an open-access article distributed under the terms of the Creative Commons Attribution License (https://creativecommons.org/licenses/by/4.0/), which permits unrestricted use, distribution, and reproduction in any medium, provided the original work, first published in the Journal of Medical Internet Research, is properly cited. The complete bibliographic information, a link to the original publication on http://www.jmir.org/, as well as this copyright and license information must be included. 